\title{
Rевенставтісі: Combining ability and heterosis prediction for grain yield of parental lines and hybrids for heat tolerance in rice (Oryza sativa L.)
}

\author{
N. SRAVAN RAJU, P. SENGUTTUVEL, A.S. HARI PRASAD, P. BEULAH, P. \\ NAGANNA, SADATH ALI, KOTESWARA RAO, SHESHUMADHAV, R.M. \\ SUNDARAM, ARUN KUMAR SINGH, JAYARAMULU, SUBBRAHMANYAM, \\ RAGUVEER RAO AND S.R. VOLETI
}

Article Chronicle:

Received :

15.07.2017;

Accepted :

30.07.2017

KeY Words:

Heterosis, Combing

ability, Rice, Spikelet

fertility, Pollen

sterility, Grain yield

heat tolerance

Author for correspondence :

N. SRAVAN RAJU

Indian Institute of Rice

Research, Rajendranagar,

HYDERABAD (TELANGANA)

INDIA

Email : sravanraju23@

gmail.com

See end of the article for

authors' affiliations
SUMMARY : Combining ability and heterosis studies conducted in three different temperature stress regimes at reproductive stage by adopting three different planting dates in fifty seven hybrid rice parental lines and different hybrid combinations. The temperature regimes were $39.8^{\circ} \mathrm{C}$ to $27.5^{\circ} \mathrm{C}$ at reproductive stage. From the results of ANOVA and kempthroren line $\mathrm{x}$ tester analysis, few hybrid combinations were found to be ideal for better parental lines development for heat tolerance with desirable traits. The elevated temperature at the time of flowering and maturity determines the yield per $s e$ of the genotypes. The hybrids adapted better than parental lines, showing the buffering nature and heterosis for stress tolerance. Under high temperature stress, the response of genotypes depended on developmental stage, but highest sensitivity was recorded at reproductive stage. Flowering stage was very sensitive to high temperature which cause pollen sterility ultimately leads to spikelet sterility. In hybrid rice seed production practices, the pollen fertility plays major role for cross pollination. The time of sowing, days to flowering, temperature at flowering time, combing ability with different CMS lines and significant positive heterosis were the crucial factors in determining the performance of hybrids to varying temperature. Hence it is necessary to select parental lines and cross combinations to identify future better hybrids. By keeping in view the above factors for different temperature stress within and across the environment.

How to cite this article : Raju, N. Sravan, Senguttuvel, P., Prasad, A.S. Hari, Beulah, P., Naganna, P., Ali, Sadath, Rao, Koteswara, Sheshumadhav, Sundaram, R.M., Singh, Arun Kumar, Jayaramulu, Subbrahmanyam, Rao, Raguveer and Voleti, S.R. (2017). Combining ability and heterosis prediction for grain yield of parental lines and hybrids for heat tolerance in rice (Oryza sativa L.). Agric. Update, 12(TECHSEAR-5) : 1213-1221; DOI: 10.15740/HAS/AU/12.TECHSEAR(5)2017/1213-1221. 